\title{
First Record of Dicephalism in a Red-tailed Bamboo Pitviper, Trimeresurus erythrurus (Cantor 1839)
}

Lal Lawmsanga ${ }^{1}$, Vanlal Hrima ${ }^{1}$, Lal Biakzuala ${ }^{2}$, and Hmar Tlawmte Lalremsanga ${ }^{2}$

${ }^{1}$ Biodiversity and Nature Conservation Network, Aizawl-796001, Mizoram, India

${ }^{2}$ Developmental Biology and Herpetology Laboratory, Department of Zoology, Mizoram University, Aizawl-796004, Mizoram, India (htlrsa@yahoo.co.in)

$\mathrm{D}$ icephalism, also known as polycephaly or dicephaly due to axial bifurcation, is a phenomenon of an animal having two heads (Kompanje and Hermans 2008). The existence of dicephalism in reptiles is well documented (e.g., Cunningham 1937; Jha and Gupta 1957; Mishra and Shah 1983; Smith and Perez-Higareda 1987; Hoser and Harris 1995; Swanson et al. 1997; Diong et al. 2003; McAllister and Wallach 2006; Wallach 1995, 2007, 2012, 2018; Beane 2009; Jandzik 2009; Spadola and Insacco 2009; Albuquerque et al. 2010, 2013; Kim et al. 2013; Pezdirc et al. 2013; Wallach and Salmon 2013; Dieckmann et al. 2014; Gvozdenovic and Cavor 2015; Twombley 2015; Caviglioli et al. 2016; Devkota et al. 2020a, 2020b). The first known appearance of dicephalism in reptiles is a 120 million-year-old fossil found in China (Buffetaut et al. 2007). The latest tabulation of verified cases of axial bifurcation in snakes lists 2,007 cases, including 221 species in 114 genera; if one includes anecdotal reports the total number of cases rises to 2,071 (V. Wallach, unpubl. data). A total of 44 cases of dicephalism have been documented in the family Viperidae, including one species in the genus Trimeresurus, the White-lipped Pitviper, T. albolabris (Wallach 2018). Herein we report dicephalism in the Red-tailed Bamboo Pitviper (Trimeresurus erythrurus) from Mizoram, India, representing the first reported case for the species and the second case for the genus.

This dicephalic Red-tailed Bamboo Pitviper was captured on 13 August 2013 by local villagers along a trail near Chhipphir Village, Lunglei District, Mizoram, India $\left(23^{\circ} 16^{\prime} 85.83^{\prime \prime N}, 92^{\circ} 79^{\prime} 66.56 " \mathrm{E}\right.$; elev. $\left.978 \mathrm{~m}\right) 62.4 \mathrm{~km}$ south of the state capital, Aizawl. The neonatal female had scoliosis just posterior to the neck, heads were completely separated, well developed, and each with two eyes (Fig. 1). The two heads bifurcate behind the jaw angle (Fig. 2). The maximum total length was approximately $310 \mathrm{~mm}$. Due to scoliosis, ventral scales from 13-26 joined with 28-37 forming a lateral fold on the left side with ventral 27 at the angle between the two adjoined rows.

The snake was inactive and about to shed the skin. After removal of the shed, it became more active but moved slowly and had difficulty climbing and crawling smoothly. Sex of the snake was determined by cloacal probe. After taking photographs, the snake was released into the surrounding forest

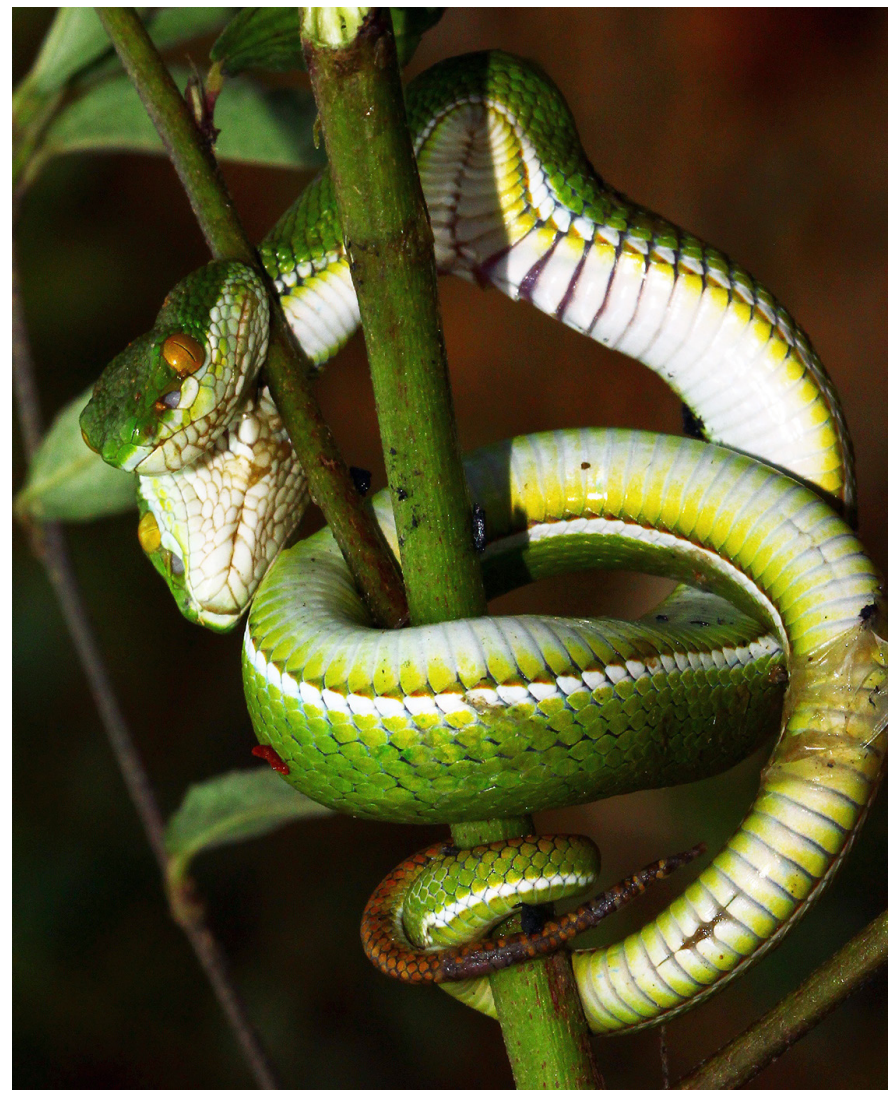

Fig. 1. A neonatal two-headed Red-tailed Bamboo Pitviper (Trimeresurus erythrurus) also with scoliosis from Chhiphir Village, Mizoram, India. Photograph by Lal Lawmsanga. 


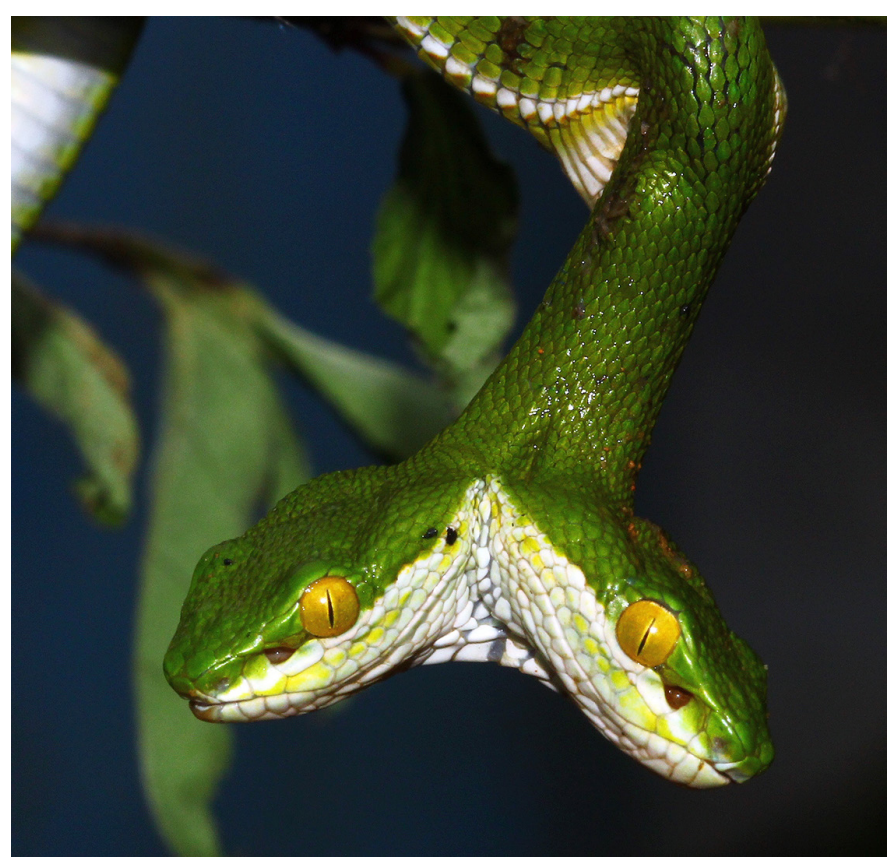

Fig. 2. The heads of a neonatal dicephalic Red-tailed Bamboo Pitviper (Trimeresurus erythrurus) from Chhiphir Village, Mizoram, India. Photograph by Lal Lawmsanga.

as the villagers were unaware that the only chance for survival of a two-headed snake is in captivity. Digital voucher images were deposited in the Lee Kong Chain Natural History Museum, National Museum of Singapore (ZRC [IMG] 2.461a,b).

Two-headed snakes rarely survive long in the wild but can survive for many years in captivity (Wallach 2007). The majority of dicephalic individuals are unable to survive and behave normally in the wild due to having two independent brains (Devkota et al. 2020a). The inability to move in a coordinated manner inevitably results in the animal's death as it cannot successfully escape predators or capture food (Devkota et al. 2020b).

A total of 41 dicephalic snakes have been documented in India (Wallach 2018). This record is the first documented case of dicephaly in Trimeresurus erythrurus and the forty-second record of dicephalism in Indian snakes.

\section{Acknowledgements}

We thank Liandawla (Chief Wildlife Warden, Environment, Forest and Climate Change Department, Government of Mizoram, India) for issuing collection permit No. A.33011/2/99-CWLW/225. We also thank DST-SERB, New Delhi, for providing financial assistance for laboratory facilities under number EMR/2016/002391.

\section{Literature Cited}

Albuquerque, N.R. de, W.S. Arruda, A.S. Costa, R.C.V. Galharte, L.G.H. Vargas, and I.H. Moreno. 2010. A dicephalic yellow anaconda snake, Eunectes notaeus (Serpentes: Boidae), from southern pantanal, Brazil. Journal of Natural History 44: 1989-1994.
Albuquerque, N.R. de, L. Piatti, and V. Wallach. 2013. Dicephalism in the green racer snake, Philodryas patagoniensis (Serpentes, Colubridae), from southeastern Brazil. Herpetology Notes 6: 85-87.

Beane, J.C. 2009. Notes on a dicephalic eastern ribbon snake, Thamnophis sairitus sauritus. Bulletin of the Chicago Herpetological Society 44: 1-3.

Buffetaut, E., L. Jianjun, T. Haiyan, and Z. He. 2007. A two-headed reptile from the Cretaceous of China. Biology Letters 3: 80-81.

Cavigiolo, L., S.A. Mella, and G. Bruni. 2016. Another case of dicephalism in Vipera aspis francisciredi (Laurenti, 1786) from northern Italy. Herpetozoa. 29: 85-86.

Cunningham, B. 1937. Axial Bifurcation in Serpents: An Historical Survey of Serpent Monsters Having Part of the Axial Skeleton Duplicated. Duke University Press, Durham, North Carolina, USA.

Diong C.H., L.K.A. Tan, and C.M.U. Leh. 2003. Axial bifurcation in a bicephalic Chelonia mydas embryo. Chelonian Conservation Biology 4: 725-727.

Devkota, K., A. Ghimire, C. Thapamagar, V. Wallach, and D. Wojnowski. 2020a. First record of dicephalism in the Common Krait, Bungarus caeruleus (Schneider 1801), from Nepal. Reptiles \& Amphibians 26: 226-229.

Devkota, K., S.B. Magar, V. Wallach, and D. Wojnowski. 2020b. First record of dicephalism in the Banded Kukri, Oligodon arnensis (Shaw 1802), from Nepal. Reptiles \& Amphibians 27: 71-72.

Dieckmann, S., G. Norval, and J.J. Mao. 2014. A description of a clutch of the Indo-Chinese rat snake, Ptyas korros (Schlegel, 1837), with notes on an instance of twinning. Herpetology Notes 7: 397-399.

Gvozdennovic, S. and N. Cavor. 2015. First record of dicephalism in the four-lined snake Elaphe quatuorlineata Lacepede, 1789 (Serpentes: Colubridae) from Montenegro. Natura Sloveniae 17: 49-50.

Hoser R. and P. Harris 1995. A second case of bicephalism in Queensland carpet snakes (Morelia spilota mcdowelli) (Serpentes: Pythonidae). Herpetofauna 3: 61.

Jandzik, D. 2009. Prodichotomy in the snake Oreocryptophis porphyraceus coxi (Schulz \& Helfenberger, 1998) (Serpentes: Colubridae). Herpetological Bulletin 107: 27-29.

Jha, V.R. and P.D. Gupta. 1957. A double headed krait, Bungarus caeruleus (Schneider). Journal of the Bombay Natural History Society 54: 947-948.

Kim, I., J.K. Kim, J.J. Fong, and D. Park. 2013. Report of a dicephalic steppes ratsnake (Elaphe dione) collected in South Korea. Asian Herpetological Research 4: $182-186$.

Kompanje, E.J.O. and J.J. Hermans 2008. Cephalopagus conjoined twins in a Leopard cat (Prionailurus bengalensis). Journal of Wildlife Diseases 44: 177180.

McAllister, C.T. and V. Wallach. 2006. Discovery of a dicephalic Western Diamondback Rattlesnake, Crotalus atrox (Serpentes: Viperidae), from Texas, with a summary of dicephalism among members of the genus Crotalus. Journal of the Arkansas Academy of Science. 60: 67-73.

Mishra, P.N. and K.B. Shah. 1983. Notes on two headed snake. Journal of Natural History Museum of Nepal7: 101-103

Pezdirc, M., A. Žagar, and M.A. Carretero 2013. First record of dicephalism in Vipera ammodytes (Linnaeus, 1758), from Slovenia. Herpetozoa 26: 94-95.

Smith, H.M. and G. Perez-Higareda. 1987. The literature on somatodichotomy in snakes. Bulletin of the Maryland Herpetological Society 23: 139-153.

Spadola, F. and G. Insacco. 2009. Newborn dicephalic Podarcis sicula. Acta Herpetology 4: 99-101.

Swanson, S., F. van Breukelen, B. Kreiser, D. Chiszar, and H.M. Smith. 1997. A double-bodied midland water snake and additions to the literature on ophidian axial bifurcation. Bulletin of the Chicago Herpetological Society 32: 80-83.

Twombley, R. 2015. A two-headed sidewinder (Crotalus cerastes) and review of axial bifurcation in snakes. Southwestern Center for Herpetological Research Bulletin 5: $57-60$.

Wallach, V. 1995. New records of dicephalic snakes in museum collections. Herpetological Review 26: 127-129.

Wallach, V. 2007. Axial bifurcation and duplication in snakes. Part I. A synopsis of authentic and anecdotal cases. Bulletin of the Maryland Herpetological Society 43: 57-95.

Wallach, V. 2012. Two-headed snakes make high maintenance pets. Bulletin of the Chicago Herpetological Society 47: 137-139.

Wallach, V. 2018. Axial bifurcation and duplication in snakes. Part VI. A 10-year update on authentic cases. Bulletin of the Chicago Herpetological Society 53: 1-20. 